\title{
Effects of lying or standing on mammary blood flow and heart rate of dairy cows
}

\author{
H Rulquin, JP Caudal
}

INRA, Station de Recherches sur la Vache Laitière, Saint-Gilles, 35590 L'Hermitage, France

Studies on the relationship between mammary uptake of metabolites and milk output as developed by Linzell (1967) required frequent standing of the animal for blood flow measurement and it was necessary to milk frequently with oxytocin. In order to carry out such studies with more normal dairy practices, we tested the effects of standing or lying on the mammary blood flow and heart rate in dairy cows.

To widen the range of blood flow covered, one lactating $(26 \mathrm{~kg} \mathrm{milk} / \mathrm{d})$ and one dry Holstein cow were used. Mammary blood flow was measured on the left common external pudic artery by a transit-time blood flowmeter. Heart rate was determined by an electronic device counting arterial blood flow pulses delivered by the non filtered output of the flowmeter. Position (up or down) of cows was registered with an "opto" sensor by the same device. Blood flow (18 data/s), heart rate and animal position (1 data/min each) were centralized continuously ( $24 \mathrm{~h} / \mathrm{d}$ ) on a computer for $5 \mathrm{~d}$.
Under our conditions (ad libitum feeding, $24 \mathrm{~h}$ lighting), the cows were lying down half of the time. On average, lying induced a $24 \%$ increase in blood flow and a $7 \%$ decrease in heart rate in the 2 cows. Similar effects have been registered in man (Ganong, 1977) as responses of the cardiovascular homeostasis to gravity. Measuring an animal only while standing led to a $13 \%$ underestimation of the average daily blood flow. For an individual cow this error can range from 7 to $18 \%$ according to the time spent lying down from day to day.

Therefore, with the reservation that the number of cows used in this trial was small, we conclude that mammary balance studies with a normal management of cows require continuous monitoring of blood flow.

Ganong WF (1977) In: Physiologie Médicale. Masson, Paris, pp 665

Linzell JL (1967) J Physiol 190, 333-346

Cows

\begin{tabular}{|c|c|c|c|c|c|c|}
\hline & \multicolumn{3}{|c|}{ Dry } & \multicolumn{3}{|c|}{ Lactating } \\
\hline & \multicolumn{6}{|c|}{ Position } \\
\hline & Down & Up & $S E D$ & Down & Up & SED \\
\hline $\begin{array}{l}\text { Time (\%) } \\
\text { Heart rate (beats/min) } \\
\text { Blood flow (l/min) }\end{array}$ & $\begin{array}{r}48 \\
69 \\
1.70\end{array}$ & $\begin{array}{r}52 \\
75^{\star} \\
1.34^{*}\end{array}$ & $\begin{array}{l}1.79 \\
1.12 \\
0.04\end{array}$ & $\begin{array}{r}53 \\
78 \\
4.56\end{array}$ & $\begin{array}{r}47 \\
84^{*} \\
3.74^{\star}\end{array}$ & $\begin{array}{l}5.16 \\
0.32 \\
0.12\end{array}$ \\
\hline
\end{tabular}

Daily means of 5 days; SED $=$ standard error of difference; ${ }^{*}=$ different at $P<0.01$. 